\title{
The educator and violent situations experience by student: Coping strategies
}

\author{
O educador e as situações de violência vividas por \\ seu aluno: modos de tratamento
}

\author{
Adinete Sousa da Costa MEZZALIRA ${ }^{1}$ \\ Raquel Souza Lobo GUZZO²
}

\begin{abstract}
Domestic violence is a dilemma for educators, and child protective services do not always effectively contribute to addressing violent situations in school or outside of school. By analyzing 721 field diaries written by psychologists working in public schools, this study seeks to identify the actions taken by educators to address situations of domestic violence experienced by their students. This study is a constructive and interpretive analysis, drawing on the investigated categories in the field diaries. The results showed seven coping strategies: (1) notification and a search for networking, (2) referrals or sharing the suspected cases with other professionals, (3) focused interventions with the family and the child in the school context, (4) reluctance to seek information regarding the child's life, (5) resistance to contacting the family, (6) anonymous accusations, and (7) the welfare perspective. We concluded that violence and the strategies with which to address this phenomenon should be considered from social, political and economic perspectives.
\end{abstract}

Keywords: Coping behavior; Domestic violence; School psychologist.

\section{Resumo}

A violência doméstica é um dilema para educadores, pois as redes de proteção à criança nem sempre contribuem para que a situação seja resolvida quer na escola, quer fora dela. Este estudo analisou 721 diários de campo de psicólogos inseridos em instituições públicas de educação, identificando as ações tomadas pelos educadores diante de situações de violência doméstica vividas pelos estudantes. Adotou-se como metodologia a análise construtiva e interpretativa, extraindo dos diários de campos as categorias investigadas. Os resultados apontaram sete estratégias de enfrentamento: (1) notificação e busca do trabalho em rede; (2) encaminhamento ou compartilhamento com outros profissionais; (3) intervenções focais com a família e a criança; (4) relutância em buscar informações sobre a criança; (5) resistência em conversar com a família; (6) denúncia anônima, e (7) postura assistencialista. Conclui-se que a violência e as formas de lidar com o fenômeno devem ser consideradas sob as dimensões social, política e econômica.

Palavras-chave: Enfrentamento; Violência doméstica; Psicologia escolar.

$\checkmark v \nabla$

${ }^{1}$ Faculdade Martha Falcão, Curso de Psicologia. R. Natal, 300, Adrianópolis, 690557-090, Manaus, AM Brasil. Correspondência paral Correspondence to: ASC MEZZALIRA. E-mail: <adinetecosta@hotmail.com>.

2 Pontifícia Universidade Católica de Campinas, Centro de Ciências da Vida, Programa de Pós-Graduação em Psicologia. Campinas, SP, Brasil.

Support: Conselho Nacional de Desenvolvimento Científico e Tecnológico. 
Violence is a phenomenon that causes serious concerns in society, and addressing this problem is challenging, especially when considering the various manners in which health and education professionals intervene in such situations. Before reflecting on the manners in which educational professionals address situations of violence, we focus on understanding this phenomenon culturally and historically. According to Martín-Baró (2003), finding the psychosocial meaning of various forms of violence in every culture or social group requires a study of the history of this phenomenon in each society.

The increase in violence must be analyzed from the perspective of the interests and concrete values that characterize each society. An act of violence may be perceived as positive or negative according to the social valuation of a particular society. Thus, identifying the rationale attributed to violent acts is essential to understanding this phenomenon in a particular community (Martín-Baró, 2003).

Guzzo, Lacerda, and Euzébios (2006) presented an important summary of violence in Brazilian schools based on Martín-Baró's psychosocial foundations, considering actions in different contexts (community, education, families, students, and management and technical staff), demonstrating that the outputs for coping with this issue are collectively constructed and adjusted to each social context.

Understanding violence as a phenomenon that encompasses many meanings and forms linked to the social context in which it occurs has led us to examine some Brazilian studies that have the reflected on how educational professionals have addressed sexual, psychological and physical violence experienced by their students. In a brief survey of Brazilian studies conducted on this topic, contributions were identified by Brino and Williams (2003), Inoue and Ristum (2008), Landini (2011), Vagostello, Oliveira, Silva, Donofrio, and Moreno (2003, 2006), Weber (2005), and Weber and Guzzo (2006). These authors investigated such topics as (a) the primary responses of educators facing a case 38 of violence, (b) identifying cases of violence, (c) the most observed modality of violence and (d) the relation between the school and outside organizations for the protection of children and adolescents.

With respect to the primary response of the school facing a case of violence (topic "a"), the procedures most often cited in the study of Brino and Williams (2003) were examining the attitudes of the school, denouncing the case, conversations with parents, talking with the child and offering help in the classroom. Vagostello et al. (2006) emphasized the following actions: calling the parents, guidance, referral to the Conselho Tutelar (CT, Child Protection Council) referral to a psychologist, and not reporting the violence.

These results reveal that reporting violence to child and adolescent protective services, as mandated by the Estatuto da Criança e do Adolescente (ECA, Child and Adolescent Statute) as the first response to suspected domestic violence, has not occurred. The authors previously cited (Vagostello et al., 2006) believe that these results provide evidence of educators' lack of preparedness and a lack of information on the subject in addition to possible difficulties in implementing legislation that requires all children to be treated equally, regardless of their economic or social levels.

Regarding the identification of violence (item "b"), most cases were identified by the victim reporting verbally. Other identification factors were also noted in the research, such as the presence of bodily marks, student behavior, school absences, and reporting by the family. An important fact evidenced by surveys is that the primary figure identifying violence in the school environment is the teacher (Inoue \& Ristum, 2008).

Regarding the most observed modalities of violence (topic " $c$ "), educators identified the following processes: physical violence (73.9\%), neglect $(46.4 \%)$, sexual abuse $(43.5 \%)$ and verbal aggression (33.3\%). A finding that merits emphasis in the study of Vagostello et al. (2006) is that in all cases of sexual violence, reporting resulted primarily from the victim's statement.

That only the victim reported sexual abuse suggests that educational professionals are not 
adequately trained to recognize indicators of such violence. Identifying an incident of violence only from a child's account, however, is tenuous because children may not be able to directly express what they have experienced in relation to the suffered violence. Conversely, the teacher, often unprepared, does not know how to address the revelation of the abuse and does not take appropriate action. For this reason, the teacher's omissive behavior may cause the child to believe that the abuse is not something serious or that the teacher does not believe his account (Brino \& Williams, 2003). This is one of the main reasons for preparing educational professionals in procedures to address this type of situation because in addition to sexual violence causing trauma to the child and the adolescent, inappropriate intervention or non-intervention can also be traumatic (Landini, 2011).

With regard to the relation between the school and the systems for child and adolescent protection (topic " $d$ "), the studies by Weber (2005) and Weber and Guzzo (2006) argue that there is no integrated preventive system linking schools and the CT and therefore there is no awareness of cohesion or integrated practices focused on the protection of the child or the adolescent. The existing cohesion between different systems is fragmented, and thus these systems must work cooperatively, making referrals together to ensure that what is legally mandated is actually accomplished. The work by Sant'Ana, Costa, and Guzzo (2008) shows how this integration between the school and life contexts can change the trajectory of suffering that many children live with.

One of the hypotheses developed to justify the difficulty of integrating these systems, at least within the school and the $C T$, is the reduced number of counselors available to visit schools and communities to clarify the school's and community's roles. Because of this lack of information, schools are uncertain as to how to proceed before referring the child to CT. Conselho Tutelar requests that documents from the school accompany the child or the adolescent, even when reporting abuse (Weber, 2005; Weber \& Guzzo, 2006).

The results of the studies presented here help to clarify why schools do not regularly address cases of domestic violence to protect children and adolescents. Given this information and enhance the understanding this situation, the present study identifies actions by educators facing situations of domestic violence involving students that were identified by observation or recorded in the Field Diaries of a group of psychologists working in normal public schools in early childhood education and elementary education between 2004 and 2010. This is an analysis of documents produced in the school context by school psychologists on the issue of domestic violence.

\section{Method}

This study is based on document research, which according to Sá-Silva, Almeida, and Guindane (2009), "is a procedure that uses methods and techniques for capturing, understanding and analyzing documents of various types" (p.5). Given this definition, this study uses as sources of information field diaries of psychologists who participated in the extension project called "Voo da águia" ("Flight of the Eagle") ${ }^{3}$. These field diaries are part of the collection of the Laboratório de Avaliação e Medidas Psicológicas (LAMP, Laboratory of Psychological Evaluation and Measures) of Pontifícia Universidade Católica de Campinas.

According to Montero (2006), field diaries present extensive and detailed written descriptions prepared in a careful and occasionally spontaneous manner detailing what was observed in the field. Thus, in the visits to two local educational institutions - one for early childhood education and one for elementary education - psychologists who

$\boldsymbol{\nabla} \mathbf{v} \boldsymbol{\nabla}$

3 This refers to an extension project coordinated by the PhD. Profa. Raquel Souza Lobo Guzzo, whose objective was the promotion and monitoring of the social and emotional development of children by discussion with families and teachers regarding education processes in different contexts and situations of everyday life. 
were part of the "Voo da Águia" project recorded episodes and/or situations occurring in schools.

The seven hundred twenty-one field diaries used in this study were produced over a six-year period (2004-2010). The analysis of the field diaries occurred in two stages: first, we developed a table containing date, acronym, identification and number of diaries. Then, in the psychologists' records in the field diaries, we identified educators' actions and manners of thinking when facing a case of domestic violence. Their actions were interpreted using the model of content analysis from the constructive-interpretive perspective presented by González Rey (2002, 2005).

Using this protocol, the researcher first identifies the indicators of meaning - in this case, the actions and manners of thinking of the educator addressing the violence. Then the researcher interprets these indicators, which are collected according to the meanings attributed to the indicators; and finally, the researcher creates the meaning cores. This manner of interpreting the data, in which the production of knowledge is a human production, reveals the active role of the researcher, making the researcher a research subject. Therefore, the categories "are instruments of the thoughts that express not only a moment of the studied object, but the historical and cultural context in which this moment appears as the meaning, and with it, the story of the researcher, which is a relevant element in explaining his creative sensibility" (González Rey, 2002, p.60).

Notably, the results observed in this study were gathered from the observations and experiences of a group of psychologists who participated in the daily school life of two public schools. Thus, the categories observed reveal these professionals' vision of how educators act in situations in which their students are subjected to violence.

\section{Results and Discussion}

The constructive-interpretative analysis of the information culled from the field diaries identified situations of violence involving students: (1) notification and search for a network; (2) referring suspected cases to other professionals or sharing cases with other professionals; (3) focused interventions with the family and the child in the school context; (4) reluctance to seek information regarding the child's life; (5) resistance to contacting the family; (6) anonymous reporting, and (7) the welfare perspective. We conclude that violence and the manner in which to address violence should be addressed from social, political and economic perspectives.

\section{Notification and the search for networking}

One procedure used by educators when faced with children who have experienced violence is a referral to institutions such as the Centro Regional de Assistência Social (Regional Center for Social Assistance), CT and the Health Center:

\begin{abstract}
The management team of the school decided to write a letter addressed to public institutions regarding a suspected case of child neglect. The father of the child did not appear at the school, the rehab center does not give out information, and the health center is far away. Thus, instead of referring the case only to the Child Protection Council, we decided to include other sectors (FD 570).
\end{abstract}

Networking can be an excellent intervention strategy for overcoming violence in the lives of children and adolescents. In Brazil, because public systems for child and adolescent protection are not interconnected to facilitate the identification, tracking and monitoring of cases, people reporting abuse often resort to recurring notification; i.e. one family has received several notifications from various sectors, exposing the weakness of the networking system:

The teacher said she filed a notification with the Child Protection Council because the child had many absences and she saw her begging [for money] in the streets while her mother was sitting on a park bench nearby. She also became aware that the girl and some kids were begging for money at a party 
and that this mother has been reported twice for negligence (FD 059).

It is extremely important that after public organizations that protect children and adolescents have been notified, the case is monitored in intersector meetings and/or an elaboration of documents disseminating information on that monitoring. This procedure was documented in the research of Sant'Ana et al. (2008), who observed that networking can contribute to the development of interventions able to ensure the physical and psychological integrity of the family.

It is important to remember that because educators generally do not have appropriate training to enable them to identify and intervene in cases of violence, as noted by Inoue and Ristum (2008), many educators have doubts regarding how to proceed in such situations:

One of the teachers asked him to discuss the daily lives of teachers, for example, what to do with an aggressive student. Should the school send students to the CT, to the Centro de Referência de Assistência Social (CRAS), Reference Center for Social Welfare, etc.? What position should the school take before a student is inserted into a risky situation? What are the alternatives for referral? (FD 402).

\section{Referring to or sharing suspected cases with other professionals}

To obtain help regarding the procedures to be followed, another strategy used by educators to cope with cases of violence against children and adolescents is the referral of cases to other professionals who are on the school site. In the case of work performed by members of the extension project "Voo da águia", the psychology team was often required to verify suspicions of abuse because they were present at the school:

The teacher named two brothers, one from the Centro Municipal de Educação Infantil (CEMEI), Municipal Center for Early
Childhood Education and the other from the Municipal School for Early Childhood Education (Escola Municipal de Educação Infantil [EMEI]). The board of directors would like us to investigate, for there is a suspicion of physical violence in addition to the fact that the boys' father is a known crack user (FD 313).

The teacher came to tell me about a boy she suspects is suffering from domestic physical violence. She reported that he was often absent, and the mother excuses him, in the notebook, for being absent because he was sick (FD 283).

That it is difficult for the educator to know how to address a suspicion of violence is understandable, considering that educational professionals are required to notify authorities in cases of violence while simultaneously being aware that the notification of an unproven suspicion can create additional difficulties for the child and, therefore, for the family (Landini, 2011). Because of this fear, some educators seek support from other professionals to address cases that present situations of vulnerability for the child or the adolescent:

The teacher asked me to talk with a student who was messing around in class, and then told me that this girl witnessed her mother being assaulted by the father's current girlfriend (it was he who held the mother for his girlfriend to hit her) (FD 259).

Landini (2011), in discussing the role of the school in a case of violence, explains that educational professionals are not required to verify a suspicion of violence because they were not prepared in their training courses to handle this type of situation. Landini (2011) argues that if the educator does not feel safe in addressing the situation, the more prudent and responsible approach is to seek help from a qualified professional at the school.

Public schools in our country, however, do not have a multidisciplinary team including psychologists and social workers that have been trained to act in these situations. 


\section{Focused interventions with the family and the child in the school context}

Educators often seek to communicate with the family or to clarify the source of bruises observed on the child's body or verify information reported by the child regarding a violent situation:

The child's face was bruised, and according to the teacher, when the mother was called to clarify the situation, the explanation given was that the child had quarreled with his brother. However, the teacher did not believe this story because the bruises indicated beating on his face (black eye), and therefore the teacher referred the case to the school board (FD 713).

The inclusion of the incident in the school record, communication with the school board and calling the family are actions that are generally part of the responses of educational professionals in situations of domestic violence. Weber and Guzzo (2006) supported this assertion when they observed in their research that when the child comes to school with evidence of some type of domestic violence, the teacher first enters the incident in the school records and has the responsible adult sign to verify the occurrence. However, because the educational professional is not certain what occurred and because there is no guarantee that reporting will in fact protect the child, often the case goes no further. Some educators believe that the family just needs guidance on how to impose limits on the child:

The teacher reported that the student had told her that that bruise was the result of a "shoe hit" that his mother had given him the night before because he "did not want to sleep". I asked if she had registered the occurrence in the school record, and she said she would not do so because the school would then want to file a complaint and she thought it was unnecessary; she just wanted to talk to the mother and accompany the child to prevent the mother from hitting the child (FD 553).

This type of action, i.e. only calling the family 42 and not notifying authorities, can become a risk for the child herself, as Vagostello et al. (2003) report. When there is no notification to the or the Varas de Infância e Juventude (Courts of Childhood and Youth) but just the calling of the family, "the school can be warning the aggressor of the visibility of his act and, to some extent, encouraging him to develop more cunning mechanisms to conceal the aggression, such as inflicting bodily injuries in less evident regions (back, chest, stomach) or even utilizing massive psychological violence (threats) to coerce the victim into silence" (p.195).

This resistance to referring cases to the $\mathrm{CT}$ may be because of the lack of clarity regarding the role of this system in schools and in society (Weber, 2005) and because of the CT's reputation for moralizing, judging, and discriminating (Sant'Anna et al., 2008). Hence, the Child Protection Council is perceived as a punitive and repressive police body and not as a place guaranteeing the rights of children and adolescents, as intended in the ECA (Weber, 2005; Weber \& Guzzo, 2006).

\section{Reluctance to seek information regarding the child's life}

In the analysis of field diaries, some records indicated that educators were giving up seeking information regarding the home life of a child suspected to be a victim of violence. This was clear when an educator avoided contact with the family:

According to the teacher, at the beginning of the year, the mother came to say that the girl would miss a few days because some things happened. I tried to understand what the teacher knew about the student, and she replied, "It seems that she had been abused by some relatives" The teacher said that her mother always takes the daughter and because of that does not know the father and does not know anything about the girl's family (FD 026).

In addition to this aggravation, some educators believed that the child imagined the violence. Note the following excerpt: 
The teacher reported that the mother sought her out because she believed her daughter had been sexually assaulted but was not sure because she was taken to the doctor and nothing was proven. However, in a conversation between the child and the pediatrician, the mother reported that the "boy" (the nephew of the girl who babysat her while her mother worked in a school) touched her butt. According to the teacher, the child is very participative and cheerful in the classroom and she did not notice any change in the child after this supposed incident; the teacher thinks it may not have happened because she considers the child quite imaginative and very creative (FD 003).

Inoue and Ristum (2008), by analyzing cases of sexual violence reported in schools, observed that many episodes of violence are ignored even when the victims report the abuse. Generally, the educational professional does not want to compromise himself or does not believe what he hears.

In some cases, when teachers notice that the child's behavior has changed, the teachers do not pursue their suspicions or confirm the violence, even when the Child Protection Council has previously notified them, as the following excerpt demonstrates:

I talked to the teacher to find out how the child was because last year she was beaten a lot and the mother brought many boyfriends inside the house. The educator said that a month ago she found the girl a little aggressive and making comments about boyfriends, about seeing them bathing, but that she spoke with the child and since then she thinks the girl is very calm and tranquil, that it may have been a phase (FD 137).

This teacher's attitude that she can help children just by having the children talk with her, according to Brino and Williams (2003), only perpetuates the problem of violence because such an approach does not remove the child from the risk situation in which she has been living, nor does talking to the child prevent the abuser from continuing the abuse.

The absence of students from school was not always explored by the educator or communicated to the administrative staff of the school, even when it involved cases of children reported by the Child Protection Council:

The teacher said that the child came only two days this week and missed the other three, and this is quite common. I asked if she had communicated the absences to the board of directors, and she answered no. We need to speak with the board of directors because this child was referred by the Child Protection Council (FD 141).

The school must be extremely alert to school absences because absences are the second most common means of identifying sexual violence, according to Inoue and Ristum (2008). In this study, the researchers observed, "in the cases in which violence has been identified by absences, the school administration called the family and knew that the victims had left their homes to go to school, but on the way, were intercepted by the aggressors" (p.19). This indicates the need for school professionals to remain attentive to the absences of their students and not consider being absent as something natural and routine.

\section{Resistance to contacting the family}

Some educators, worried about the physical and psychological integrity of the child, avoid calling parents to clarify situations of suspected domestic violence:

We talked to the teacher about the child when we collected some information, but the data are confusing because the child's life is confusing. The teacher said she will not call the mother for now for fear that the child will be beaten for saying something (FD 032).

The fear of calling the family to clarify information reported by the child or to ascertain the causes of bruises appearing on the child's body 
is addressed in the literature and is especially prevalent in schools that are in violent communities and in areas of organized crime. Inoue and Ristum (2008) described the case of a child who reported that the stepfather "practiced sexual acts with her"; the teacher called the mother to investigate this situation, and the family has not taken the child to school since then and changed their address. Stories such as this are frequent in the educational context but appear to have little effect on the evaluation and implementation of child protection policies integrated into psychosocial networks. When the family disappears, it becomes nearly impossible to protect the child in other social and educational contexts.

Other factors also cause a family to disappear with a child when a violent situation occurs. The field diaries we were working with recorded the case of a child who had suffered sexual abuse, and the "leaders" of the neighborhood from making the accusation prevented the mother. To prevent policemen or professionals who represent public organizations from entering the community, these same "leaders" assaulted the abuser and expelled him from the neighborhood. The mother, aware that the school would make the accusation of sexual abuse as a child protection measure, took the daughter out of school and left the neighborhood.

Thus, calling the parents to clarify suspicions of violence may jeopardize the child and the family. Because of this fear and the possible consequences, some educational professionals avoid or are extremely cautious in their conversations with those responsible for the child. In addition, educators also report that they feel isolated when faced with this type of situation without the support of other school professionals:

The teacher told me that she was very angry because the administrative staff at the school did not want to join the conversation with the parents (the child reported that he had seen a porn movie) (FD 126).

\section{Anonymous accusation}

Occasionally, educators make anonymous 44 accusations as a way to protect the student in cases of domestic violence. This is expressed in the following excerpt:

The educator said she would make an
anonymous accusation by phone and not
be identified; she mentioned the case of a
former student and stressed that educators
are afraid to make an accusation because
the school is in a community surrounded by
drug dealing (FD 126).

Notably, the accusation, even though it is anonymous, does not always ensure the accuser's safety. Weber (2005) observed that in most cases, educational professionals do not make accusations because they do not receive the necessary protection from the state. Consequently, despite reporting episodes of violence, children and adolescents increasingly realize that they are not heard and repeatedly experience violence.

I talked with the teacher about the child and asked if she knew anything of his life; then she said that she knew his father had died and his mother is in prison. I asked if she knew why, to which she told me she did not want to know and that she knows that he is the nephew of the village trafficker (FD 037).

Notably, the educator's indifference to the child's life context is guided by extramural school factors that endanger the safety of the professional; therefore, he chooses not to explore his student's life to avoid encountering situations that will require immediate action, in this case, the accusation. Therefore, to avoid an ethical, political and social dilemma, he assumes a posture of indifference, focusing on the pedagogical work to justify not having to choose between legally responding to the child's situation or running the risk of suffering reprisals from the community (Costa, 2010; Mezzalira \& Guzzo, 2011). Thus, the fear in their reports must be considered when we make assumptions regarding an educator's involvement with children. The fact is that the "law of silence" imposed on these communities makes the accusation a rare occurrence:

The teachers were very concerned with the children because they lived in a community controlled by drug dealing, and several times 
they observed their students replicating behaviors experienced at home such as picking up cigarettes, always being the thief in the play, being angry with the police, cringing when a helicopter passed, and trying to hide. Teachers believe that these children are children of drug dealers. The teachers report their fear of getting involved. They want to help the children but are afraid of being killed. They say that in the community, the "law of silence" reigns if one does not want to suffer reprisal (FD 578).

Thus, the child or adolescent victims of domestic violence remain unprotected by teachers and other professionals. The notes contained in the FD demonstrate that the intimidation suffered by these professionals was not only demonstrated in the reports and in relation to the "leaders" of the community but also concretely experienced in various manners. Educational professionals who have followed the path of accusation, investigation, detection and monitoring of a child or of an adolescent subjected to violence and demanded protective action on the part of family at some point have felt threatened by the family or the student:

The board of directors noted some cases of students who have problems with drugs and robberies and spoke of the threats suffered in the school (FD 198).

Facing this fear, some educators have refused to report violent situations to the school:

The intern came to inform me that the child had a bruise from a belt buckle on her forehead, according to the girl's account. When talking to the teacher about the steps that were taken, I was informed that this situation was not recorded at the school (DC160).

Given the complexities of this situation, it is crucially important to identify coping strategies that ensure the safety of accusers so that cases of domestic violence are able to extend beyond the school walls and reach the appropriate systems of child and adolescent protection (Weber \& Guzzo, 2006).

\section{Welfare perspective}

Some educators use the welfare system as a means of addressing violence experienced by students. Coping with violence with individual and local responses without joint planning or developing public policies does not lead to any progress in changing the reality of violence in children's lives.

\begin{abstract}
The teacher said that the child's mother is negligent. The teacher revealed that she has already given the mother clothes to give to the child several times because the teacher feels very sorry for the child, but the child has never appeared in the clothes; therefore, the teacher has given up, saying that there is nothing else to do (FD 110).
\end{abstract}

Educators' individual actions have little effect on the everyday life of the school and have even less effect on the everyday violent lives of students. We believe that a practice in which one person is placed in the role of "giving" and the other in the role of "receiving" will not change reality nor help individual students unless there is a joint political discussion regarding the factors that perpetuate this type of situation.

By bringing this analysis to situations of neglect and child abandonment, we realize that making donations or labeling parents as irresponsible, incapable or unsuccessful, will not resolve this situation. Instead, communities must promote collective discussions that seek to build public and social policies to ensure the basic conditions for survival for families, such as food, housing, health and education.

Faced with this exclusionary system, the educator, by engaging with the life context of children and their families, experiences a whirlwind of feelings that can lead to the educator's illness and the recurrent use of medications:

The number of educators from that group who take prescription medications was... raised. Of eight teachers, six take some type of tranquilizer. This is worrisome because they are professionals who are experiencing health problems, many of an emotional nature, and they are working with children. 
Some teachers are no longer able to wait for the time to retire" (FD 319).

In general, these results identify the initial actions and feelings of educators when their students are victims of violence, before resorting to reporting and referrals. Reading and analyzing these records gave us access to a small sample of how schools have acted in response to cases of domestic violence. Intervention strategies, accusations and the search for support in the health, education, social welfare and judicial sectors are some of the procedures mandated for the school or the community in situations of physical, sexual, institutional or psychological violence. Despite these mandates, many situations remain masked by other educational practices. A distance remains between the school and the community; this distance is maintained both as a consequence of the need to protect educators and as a result of the ineffectiveness of psychosocial networks to protect and prevent.

The results of this study combined with data from the literature have revealed, however, that schools do not use reporting as a first response to violence. Given this reality and because accusations rarely occur, the child and the adolescent are unprotected and are not supported by a specialized team. In fact, several factors affecting the everyday life of a public school in a community marked by exclusion and violence hinder violent offenders from being accused. ECA (Brasil, 1990) obliges professionals to file reports or face punishment. Nevertheless, our country does not have a network in place to protect professionals who accuse violent offenders.

The lack of preparedness and the fear evident in the educators' accounts must be considered when questioning educators' level of involvement with the children. It is clear that educators know the children's life context but do not share information to avoid reprisals; educators are afraid to explore the child's life situation and are in a dilemma regarding how to respond. Therefore, the feelings of fear and helplessness when confronted with the violence and neglect to which school children are subjected have hampered 46 the actual reporting of abuse.
Guzzo (2005) reflected on the attitudes of educators toward the children's life histories. Guzzo (2005) considered the educators' fear when they became aware of this reality because teachers did not want to compromise themselves and thus did not know how to handle the situation. In addition to teachers not wanting to report abuse, the school protects itself with an attitude of non-involvement in the personal issues of their students and their students' families. The problems are "referred" out of the school in an attempt to have the problems be resolved outside of the classroom. In general, this manner of coping with violence has been one of the factors causing psychological illness in educators. Teachers feel helpless and unprotected; thus, to protect themselves, they remove themselves from the problem.

Therefore, we argue that violence and the ways to address this phenomenon should be addressed from social, political and economic dimensions. In our country, laws such as the ECA (Brasil, 1990) have been passed to attempt to protect children and adolescents and ensure their rights; unfortunately, these laws are not accompanied by concrete changes in the reality of our society that would make these laws viable. Although individual actions to cope with the violence do exist and occasionally protective bodies such as the Centro de Referência de Assistência Social (Reference Center for Social Welfare), the Centro de Referência Especializado de Assistência Social (Specialized Reference Center for Social Welfare), the $\mathrm{CT}$, and the Health Center are involved, solutions do not occur at the collective level because the networks are fragmented and disarticulated.

Therefore, it is essential for schools and agencies to search together for ways to monitor children and adolescents without threatening the physical integrity of family and educators. We emphasize that reporting abuse is necessary; however, accusations do not change the reality of the child and the school. Although reporting is an essential step in the protection of children and adolescents, accusations alone cannot reverse the complexities of violence. Therefore, networking and program prevention policies are essential. 
Rethinking educational policy and public policies to protect children, their families and their teachers is an urgent task for those professionals who want a better environment in which children may develop and grow in our schools and communities (Guzzo, Moreira, \& Mezzalira, 2013; Mezzalira, Weber, \& Guzzo, 2013; Moreira, 2010; Sant'Ana et al., 2008). Research and studies on this subject must result in concrete proposals for the implementation of psychosocial practices. This is the task of the praxis that integrates and effects the relation between theory and practice for social change and, consequently, for the change in the development of children and adolescents.

\section{References}

Brasil. Presidência da República (1990). Lei n 8.06, de 13 de julho de 1990. Dispõe sobre o Estatuto da Criança e do Adolescente. Lei: Estatuto da Criança e do adolescente.

Brino, R. F. \& Williams, L. C. A. (2003). Concepções da professora acerca do abuso sexual infantil. Cadernos de Pesquisa, (119), 113-128.

Costa, A. S. (2010). Desenvolvimento da criança na educação infantil: uma proposta de acompanhamento (Tese de doutorado não-publicada). Pontifícia Universidade Católica de Campinas.

González Rey, F. (2002). Pesquisa qualitativa em psicologia: caminhos e desafios. São Paulo: Thomson Pioneira.

González Rey, F. (2005). Pesquisa qualitativa e subjetividade: os processos de contrução da informação. São Paulo: Thomson Pioneira.

Guzzo, R. S. L. (2005). Escola amordaçada: compromisso do psicólogo com este contexto. In A. M. Martínez (Org.), Psicologia escolar e compromisso social. Campinas: Alínea.

Guzzo, R. S. L., Lacerda Jr, F., \& Euzébios Fo, A. (2006). School violence in Brazil: A psychosocial perspective. In S. R. Jimerson \& M. J. Furlong (Eds.), Handbook of school violence and school safet from research to practice (pp.499-509). New Jersey: LEA Publishers.

Guzzo, R. S. L., Moreira, A. G., \& Mezzalira, A. S. C. (2013). Intervenção psicossocial: teoria e prática na inserção do psicólogo em instituições públicas de ensino. In M. E. Bernardo, R. S. L. Guzzo, \& V. L. T. Souza. Psicologia social: perspectivas críticas de atuação e pesquisa. Campinas: Átomo.
Inoue, S. R. V \& Ristum, M. (2008). Violência sexual: caracterização e análise de casos revelados na escola. Estudos de Psicologia (Campinas), 25(1), 11-21. doi: 10.1590/S0103-166X2008000100002

Landini, T. S. (2011). O professor diante da violência sexual. São Paulo: Cortez.

Martín-Baró, I. (2003). Las raíces estructurales de la violência. In I. Martín-Baró. Poder, ideologia y violencia: edición, introducción y notas de Amalio Blanco y Luis de La Corte. Madrid: Editorial Trotta.

Mezzalira, A. S. C. \& Guzzo, R. S. L. (2011). Acompanhamento e promoção do desenvolvimento na educação infantil: algumas contribuições da psicologia escolar. Revista Aletheia, (35-36), 22-35.

Mezzalira, A. S. C., Weber, M. A. L., \& Guzzo, R. S. L. (2013). Educadores de crianças: condições de vida e trabalho. Psicologia: Ciência e Profissão, 33(3), 688-699.

Montero, M. (2006). Hacer para trasnformar: el método em la psicología comunitária. Buenos Aires: Paidos Iberica.

Moreira, A. P. G. (2010). Situação-limite na educação infantil: contradições e possibilidades de intervenção (Dissertação de mestrado não-publicada). Pontifícia Universidade Católica de Campinas.

Sá-Silva, J. R., Almeida, C. D., \& Guindane, J. F. (2009). Pesquisa documental: pistas teóricas e metodológicas. Revista Brasileira de História \& Ciências Sociais, 1(1). Recuperado em junho 11, 2012. de www.rbhcs.com/ index_arquivos/Artigo.Pesquisa\%20documental.pdf

Sant'Ana, I. M., Costa, A. S., \& Guzzo, R. S. (2008). Escola e vida: compreendendo uma realidade de conflitos e contradições. Pesquisas e Práticas Psicossociais, 2(2), 302-311.

Vagostello, L., Oliveira, A. S., Silva, A. M., Donofrio, V., \& Moreno, T. C. (2003). Violência doméstica e escola: um estudo em escolas públicas de São Paulo. Paidéia, 13(26), 191-196.

Vagostello, L., Oliveira, A. S., Silva, A. M., Donofrio, V., \& Moreno, T. C. (2006). Práticas de escolas públicas e privadas diante da violência doméstica em São Paulo. Revista de Psicologia da Vetor Editora, 7(1), 87-94.

Weber, M. A. L. (2005). Violência doméstica e rede de proteção: dificuldades, responsabilidades e compromissos (Dissertação de mestrado não-publicada). Pontifícia Universidade Católica de Campinas.

Weber, M. A. L., \& Guzzo, R. S. L. (2006). Violência doméstica e rede de proteção: dificuldades, responsabilidades e compromissos. Em Debate, 1(4), 1-23.

Received: November 23, 2012

Final version: October 1, 2013

Approved: December 18, 2013 
